\title{
CREATIVE INDUSTRY DEVELOPMENT BASED ON ENTREPRENEURSHIP TRAINING IN DEVELOPING LOCAL ECONOMY IN PAREPARE CITY
}

\author{
${ }^{1}$ Muhammad Rakib, ${ }^{2}$ Muchtar Yunus, ${ }^{3}$ Nur Amin MT \\ 1,2 Universitas Negeri Makassar, ${ }^{3}$ Universitas Pendidikan Indonesia \\ Email: rakib feunm@yahoo.com
}

\begin{abstract}
This study aims to determine the development of creative industries, the usefulness of the implementation of entrepreneurship training, the factors that support and inhibit, and formulate a creative industry development strategy based on entrepreneurship training in an effort to develop local economic areas in the city of Parepare. This research is a type of evaluation research using a qualitative approach. This research was conducted in Parepare Town of South Sulawesi. The subjects of the study were the participants of entrepreneurship training in Kota Parepare, and the Department of Manpower of Parepare City as the manager and implementer of training through UPTD BLK Kota Parepare. Data collection techniques used are Document study, observation, and interview. Data analysis techniques include: (a) Data processing, which consists of categorization and data reduction, (b) data presentation, (c) data interpretation, and (d) drawing conclusions/verifications. The results show that (1) The development of creative industries through entrepreneurship training includes: Information and Communication Technology, Garment Apparel, Beauty, Building, Electrical Engineering, Electronic Engineering, Refrigeration, Manufacturing Engineering, and Welding Technique; (2) The usefulness of the implementation of entrepreneurship training that can shorten the learning period, improve business performance, establish attitudes, help solve business operational problems, prepare entrepreneurs to acquire expertise in certain fields, and produce output that has the ability and knowledge that qualified (3) There are several factors that support and hinder the development of creative industries through entrepreneurship training in developing creative industries, both internal and external factors, and (4) development strategy based creative industry entrepreneurship in an effort to develop the local economy of recruitment and selection of trainees, selection of training instructors, the provision of facilities and infrastructure, curriculum development, and the provision of funds or training budgets.
\end{abstract}

Keywords: Creative industry, entrepreneurship training, the local economy

\section{ABSTRAK}

Penelitian ini bertujuan untuk mengetahui pengembangan industri kreatif, kebermanfaatan dari pelaksanaan pelatihan kewirausahaan, faktor-faktor yang mendukung dan menghambat, dan merumuskan strategi pengembangan industry kreatif berbasis pelatihan kewirausahaan dalam upaya mengembangkan ekonomi lokal daerah di kota Parepare. Penelitian ini merupakan jenis penelitian evaluasi dengan menggunakan pendekatan kualitatif. Penelitian ini dilaksanakan di Kota Parepare Sulawesi Selatan. Subjek penelitian adalah masyarakat peserta pelatihan kewirausahaan di Kota Parepare, dan Dinas Tenaga Kerja Kota Parepare sebagai pengelola dan pelaksana pelatihan melalui UPTD BLK Kota Parepare. Teknik pengumpulan data yang digunakan yaitu: Studi dokumen, observasi, dan wawancara. Teknik analisis data meliputi: (a) Pengolahan data, yang terdiri dari kategorisasi dan reduksi data, (b) penyajian data, (c) interpretasi data, dan (d) penarikan kesimpulan-kesimpulan/verifikasi.Hasil penelitian menunjukkan bahwa (1) Pengembangan industri kreatif melalui pelatihan kewirausahaan meliputi: Teknologi Informasi dan Komunikasi, Garmen Apparel, Tata Kecantikan, Bangunan, Teknik Listrik, Teknik 
Elektronika, Refrigeration, Teknik Manufaktur, dan Teknik Las; (2) Kebermanfaatan dari pelaksanaan pelatihan kewirausahaan yaitu dapat mempersingkat masa belajar, meningkatkan kinerja usaha, membentukan sikap, membantu memecahkan masalahmasalah operasional usaha, mempersiapkan para pengusaha memperoleh keahlian dalam bidang tertentu, dan menghasilkan luaran yang mempunyai kemampuan dan pengetahuan yang mumpuni sehingga para pengusaha memperoleh rasa aman dan dihargai, dan menimbulkan kepuasan dalam dirinya, (3) Terdapat beberapa faktor yang mendukung dan menghambat pengembangan industri kreatif melalui pelatihan kewirausahaan dalam mengembangkan industry kreatif, baik factor internal maupun eksternal, dan (4) Strategi pengembangan industry kreatif berbasis pelatihan kewirausahaan dalam upaya mengembangkan ekonomi local yaitu rekuitmen dan seleksi peserta pelatihan, pemilihan instruktur pelatihan, penyediaan sarana dan prasarana, pengembangan kurikulum, dan penyediaan dana atau anggaran pelatihan.

Keywords: Industri kreatif, pelatihan kewirausahaan, ekonomi lokal

\section{INTRODUCTION}

Development of local economy is a concept of regional economic development based on the utilization of local resources that exist in a society, both human resources (SDM), natural resources (SDA) and institutional resources (SDL). The utilization of these resources is done by the community itself with the local government as well as existing community-based institutional groups. This oriented or locally based economic development is more emphasized on the process of enhancing the roles and initiatives of local communities in the development of economic activities and increasing productivity. This solution is more effective and successful in addressing people's welfare issues, compared to global solutions.

One of the reasons for the development of the creative industry potential is the positive impact that will affect the social life, business climate, economic improvement, and also impact on the image of a region so as to support the local economy. The impact is supported by the existence of newness and innovation, both concerning products or services that always encourage people to visit, see, know, feel or even want to buy products or services traded. It is directly or indirectly able to become the object and tourist attraction (tourist destinations) that can encourage the tourists to come or visit an area where the existence of these creative industries.

Each region in Indonesia has the potential of each that can be developed into a creative industry that is able to become a tourist destination respectively. Parepare City is one of the cities in South Sulawesi province located in a bay overlooking Makassar Strait. The northern area of Parepare is adjacent to Pinrang regency in the east, Sidenreng Rappang regency in the east and Barru regency in the south. Although located on the edge of the sea but most of the contours of the City area of Parepare is hilly.

The agricultural products of Parepare are seeds of cashew nuts, cocoa beans, and other crops and rice. The parepare farming area is quite narrow because the land is mostly rocky rocks and easy to grow grass. This area is actually very suitable for farms. Many residents in the hilly areas breed chickens and laying hens, while grassland areas are also used by local residents to shepherd goats and cows. As for the people who live on the coast are many who work as fishermen.

The Potential Parepare city can be synergized with the pattern and direction of industrial development, especially the creative industries to produce products with high competitiveness. Utilization of these potentials can be an opportunity for the community to produce a product that has high economic value. Potential human resources owned by the city of Parepare is very strategic to support the management of Small and Medium Enterprises (SMEs) as well as local resource-based creative industries in Parepare City. 
Potential management should be balanced with the willingness and ability/skill of the community in developing the entrepreneurial spirit in the city of Parepare.

Parepare city government has made various efforts in improving the entrepreneurial spirit of a society in order to strengthen economic development. One of them is through training in increasing the competence and productivity of community-based labour. In addition, Parepare city government has also provided assistance to several existing businesses such as sewing business, screen printing business, making bags and sandals, as well as various culinary seafood as well as making various souvenirs. These efforts amounted to seven groups with a total membership of 140 people.

Based on the description of the background, the author is interested to lift a title of research that is, "Development of Creative Industry Based Entrepreneurship Training in Developing Local Economy in the City of Parepare". The purpose of the research is to know; (1) the development of creative industries through entrepreneurship training in developing the local economy; (2) the usefulness of implementing entrepreneurship training on developing creative industry in developing local economy; (3) what factors support and hinder the development of creative industry through entrepreneurship training in developing creative industry; and (4) to formulate a creative industry development strategy based on entrepreneurship training in an effort to develop local economy in Parepare.

\section{THEORETICAL BASIS}

\section{Creative Industry Concept}

A creative industry mapping study conducted by the Ministry of Trade of the Republic of Indonesia in 2007 provides the definition of creative industry, namely, "Industries derived from the utilization of creativity, skills and individual talents to create welfare and employment through the creation and utilization of the creative power and creativity of the individual ". While Jerusalem (2012) argues that, the creative industry is an industry that has authenticity in individual creativity, skills and talents that have the potential to generate revenue and job creation through the exploitation of intellectual property.

Simatupang (2008: 69) also explained that the creative industry is an industry that relies on talents, skills, and creativity that are the basic elements of each individual. The main elements of the creative industry are creativity, expertise, and talent that has the potential to improve welfare through the offering of intellectual creations. understanding as a creativity-based activity that affects the economy or the welfare of society.

Based on various previous opinions it can be concluded that the creative industry is an industry based on the utilization of talents, skills and skills to generate innovation, new ideas from creative human resources. Subsectors that are creativity-based industries consist of: (1) Advertising, (2) Architecture, (3) Goods market, (4) Handicrafts, (5) Designs, (6) Fashion Videos, films and photography, (7) Games interactive, (8) Music, (9) Performing arts, (10) Publishing and printing, (11) Computer and software services, and (12) Television and radio.

The creative economy will be potential if it is supported by three things: Knowledge Creative, Skilled Worker and Intensive Labor. Skills from human resources are key to the development of the creative industry. It can be optimized through various training programs.

\section{Entrepreneurship training}

According to Kamil (2010: 3 ), the term training is a translation of the word "training" in English. Literally, the root of "training" is "train", which means: (1) giving teaching and practice, (2) making it grow in the desired direction, (3) preparation (preparation), and practice (practice). Davis (1998: 44) argues that training is a process for developing skills, disseminating information and updating behaviour and helping individuals or groups in an organization to be more effective and efficient in doing work. From that opinion, it can be seen that training is needed to help employees or individuals to improve the quality of work. 
Furthermore, Flippo (2002) suggests that: "Training is the act of increasing the knowledge and skill of an employee for doing a particular job" (training is the act of increasing the knowledge and skills of an employee to carry out a particular job). Simamora (1995: 287) defines training as a series of activities designed to enhance the skills, knowledge, experience, or individual attitude changes.

Based on some of the above opinions it can be understood that Training is a process in developing the skills of existing human resources in order to increase the productivity of its work, as well as attempted to have relationships with certain jobs. Moekijat (1991) put forward the general objectives of the training namely; (1) to develop skills development so that work can be completed more efficiently and effectively, (2) to develop knowledge so that work can be rationalized, and (c) to develop attitudes so as to generate a willingness to cooperate.

In this research, the training is skill training to Parepare city community based on creative industry. The city government strives to provide activities to the community in developing their entrepreneurial spirit based on the local economy of the region in order to improve the economic level of the community.

The training process needs to be evaluated on the prepared criteria so that the success and failure of the training can be known and can be used for the preparation of subsequent training procedures along with the necessary breeding of the existing model the training process.

\section{Supporting Factors and Inhibitors of Training Implementation}

Supporting factors and impediments to the training can be derived from the internal environment and the external environment of the training program. According to Sudjana (2007: 101), the internal environment is a lack of skill training systems, training programs, human resources, and management training. While the external environment includes the limitations of the social environment and the natural environment associated with training.

Training systems that do not contain complete, comprehensive components, processes and objectives are likely to hamper the expected outcome impacts. Training elements that typically consist of insufficient inputs, inputs, processes and outputs will result in low levels of training accountability to the achievement of the goals of the training provider or community.

\section{Local Economic Development}

Development of local economy is a concept of regional economic development based on the utilization of local resources that exist in a society, both human resources (SDM), natural resources (SDA) and institutional resources (SDL). The utilization of these resources is done by the community itself with the local government as well as existing community-based institutional groups.

The primacy of a locally oriented or locally oriented economic development emphasizes the process of enhancing the role and initiative of local communities in the development of economic activity and productivity improvement. In an effort to achieve these objectives, local governments and communities should contribute to taking initiatives in local economic development that can be undertaken through a partnership forum

Partnership for Local Economic Development is a concept that seeks to integrate the various potential resources and activities held by all stakeholders in a region. The development of economic potential can be initiated by establishing networks, the use of tools to process potential commodities, the absorption of employment opportunities and the increase of people's incomes in the region. To implement the concept developed a partnership institution between government - private - community. Therefore, local governments and the public and private sector should be able to optimize the use of existing resources effectively. 


\section{The Influence of Creative Industry on Local Economy}

Economic development of a region is an important pillar for the implementation of the development process in all fields. Because if the economic development of a region succeeds, then other areas such as law, politics, agriculture, and others will be very helpful (Dumairy, 1997). The industry sector is believed to be a sector that can lead other sectors in an economy toward progress. Industrial products always have a high or more profitable 'base of trade' and create greater added value than other sector products. This is because the industrial sector has a variety of products that are very diverse and able to provide high marginal benefits to the wearer.

Industry sector advantages such as contributing to the absorption of labour and able to create value added (value added) is higher on the various commodities produced. According to Economic Development Theory, the higher the contribution of the Industry sector to the Economic Development of the country then the country progresses. If a country's industrial sector contribution is above $30 \%$ then it can be said that the country is classified as a developed country (Sukirno, 2002).

According to the Trade Department of RI (2007), creative industries in various countries in the world today is believed to contribute significantly to the nation's economy. When viewed from the resources owned by the Indonesian Nation, the creativity of Indonesian society can be equated with other nations in the world. This is evidenced by the various works of the nation's children recognized by the international community. Indonesia is currently ranked 43rd in the Economic Creativity Index Ranking published by the World Economic Forum.

In addition, the Creative Industry can provide a very broad role in improving the image of national tourism and its presence is able to lift and develop local cultural heritage. Based on the existing observations, it can be concluded that creative economy is believed to be able to answer the national short-term and medium-term problem challenges, namely: (1) high contribution to national economic growth (average $7.28 \%$ per annum); (2) labor absorption amid high unemployment (7.75\%), and (3) an active role in international trade.

\section{METHODOLOGY}

This research is a type of evaluation research using a qualitative approach to know the success of training program that has been implemented by the government in developing the creative industry to develop the local economy. This research was carried out in Parepare Town of South Sulawesi, with the subject of the study: the participants of entrepreneurship training in Kota Parepare, the chief of the youth and the Manpower Office of Parepare City as the manager and the training implemented. The data collection techniques used are document studies, observations, and interviews. While the data collection procedure in this study consists of two stages, the first is the preparation stage that includes the initial survey activities and composing the research instrument consisting of: (1) interview guides, (2) observation sheets, and (3) SWOT analysis instrument. The second phase is the stage of research implementation. Data that has been through the triangulation stage will then go through the analysis and interpretation phase of the data covering: (a) Data processing, which consists of categorization and data reduction, (b) data presentation, (c) data interpretation and, (d) conclusion/verification. While the data obtained through the instrument to identify internal and external factors in the form of strengths, weaknesses, opportunities, and threats to creative industry development using SWOT analysis. 


\section{RESULTS AND DISCUSSION \\ Development of Creative Industry through Entrepreneurship Training in Developing Local Economy}

Entrepreneurship training is one of the most important steps to develop the creative industry. The development of creative industries will be more successful if supported by successful trainees in their business. Entrepreneurs who become entrepreneurs are potential for the development of creative industries, both in quantity and quality.

Head of UPTD BLK Kota Parepare believes that "entrepreneurship training is required not only to prepare Human Resources (HR) who are ready to work, but also must be able to prepare and open new job opportunities. Opening and expanding new job opportunities is an indicator of the growth of the creative industry. In the effort to open new jobs, entrepreneurship training is required for some components of society. One of the educational institutions that can assist in building and developing entrepreneurship in the community through the implementation of entrepreneurship training, namely UPTD BLK Kota Parepare. The advantage of entrepreneurship training in the community environment is that they can directly practice the skills acquired in entrepreneurship training.

The training held at UPT BLK Kota Parepare is a research based on Creative Economy (Ekraf) covering: (1) Information and Communication Technology with expertise: Networking, Technical Suport, Computer Engineering, Programming, Multimedia, Database, System Analyst, Graphic Design, Office Tools, Artificial Intelligence, IT Governance, and Public Relation, (2) Garment Apparel, with keahilain field: Sewing (Knitting, Woven), Embroidery Technique and Pattern Technique, (3) Beauty Treatment cover hair and makeup, (4) ) Building, with area of expertise: Construction of Stone and Concrete, Wood Construction, Building Image, Furniture, Light Steel Construction, Gypsum Work, Survey and Mapping, and Pembesian, (5) Electrical Engineering, with area of expertise: Information Installation, Power Installation, and Industrial Automation, (6) Electronic Engineering, with areas of expertise: Telecommunication, Instrumentation and Control and Audio Video, (7) Refrigeration, with areas of expertise: Production Machinery, Installation of Pipes, Work Plates, Metal Casting and CNC (Computer Numeric Control), (8) Manufacturing Techniques, including areas of expertise: Production Machinery, Pipe Installation, Work Plates, Metal Casting and CNC (Computer Numeric Control), and (9) Las, with areas of expertise: Industrial Welding, Manufacturing and Underwater Lines.

This entrepreneurship training activity, can improve the skills of the participants and foster their entrepreneurial spirit. By building their entrepreneurial spirit and providing various skill sets, it is hoped that in the end will form potential young entrepreneurs. This means that trainees are expected to have certain experience and practical skills that will be used as capital to open or create new business.

\section{The Effectiveness of the Implementation of Entrepreneurship Training on Creative Industry Development in the City of Parepare}

Developing creative industries requires sufficient skills and knowledge from business actors. Proper entrepreneurship training can be an alternative to improve the soft-skill of business actors. Based on the results of interviews with some informants can be raised some of the benefits of entrepreneurship training on creative industry development in the city of Parepare as follows:

1) Shorten the learning period to meet specified performance standards.

2) Improve job performance.

3) Contribute to the formation of attitudes.

4) Help solve daily operational problems of the company.

5) Have long-term goals in preparing entrepreneurs and acquiring expertise in specific areas that companies need,

6) Produce outcomes that have the ability and knowledge of qualified that can improve the security, appreciation, and satisfaction of the entrepreneurs. 


\section{Factors that support and hinder the development of creative industries through entrepreneurship training}

The factors that support and hinder the development of the creative industry through entrepreneurship training in Parepare City can be divided in the form of internal and external factors as the result of interviews with some informants in this study. The results of the interview are summarized and evaluated using a matrix consisting of:

\section{Internal Factor Evaluation (IFE) Matrix and External Factor Evaluation (EFE)}

\section{- Internal Factor Evaluation (IFE) Matrix}

External Analysis aims to identify the strengths and weaknesses of entrepreneurship training implemented at UPTD BLK Kota Parepare in the face of changes in its internal environment analyzed using the IFE Matrix. The results of IFE Matrix processing can be seen in the following table.

Table 1.

Evaluation of Internal Factors of Creative Industry Development through Entrepreneurship Training

\begin{tabular}{|c|c|c|c|c|}
\hline No & Internal Factors & $\begin{array}{l}\text { Weight } \\
\text { (a) }\end{array}$ & $\begin{array}{l}\text { Rating } \\
\text { (b) }\end{array}$ & $\begin{array}{l}\text { Value } \\
\text { (a)x(b) }\end{array}$ \\
\hline \multicolumn{5}{|c|}{ 1. Strength $(+)$} \\
\hline & $\begin{array}{l}\text { 1. Develop individual skills so that participants can } \\
\text { learn all aspects of their work }\end{array}$ & 0,15 & 4 & 0,6 \\
\hline & $\begin{array}{l}\text { 2. Gain experience on how to interact in the work } \\
\text { environment }\end{array}$ & 0,05 & 2 & 0,1 \\
\hline & $\begin{array}{l}\text { 3. Extend connections especially in acquiring new } \\
\text { knowledge in the field itself }\end{array}$ & 0,15 & 3 & 0,45 \\
\hline & $\begin{array}{l}\text { 4. Provide direction quickly to the intended target } \\
\text { 5. Allow training participants to perform high-risk }\end{array}$ & 0,05 & 4 & 0,2 \\
\hline & $\begin{array}{l}\text { activities in a safe environment without harmful } \\
\text { implications }\end{array}$ & 0,1 & 4 & 0,4 \\
\hline & $\begin{array}{l}\text { 6. Can improve the skills of trainees and let learn } \\
\text { from mistakes. }\end{array}$ & 0,15 & 4 & 0,6 \\
\hline & $\begin{array}{l}\text { 7. Participants are taught to think in action, } \\
\text { effective decision making and communication. }\end{array}$ & 0,15 & 4 & 0,6 \\
\hline \multirow[t]{5}{*}{2.} & Weakness (-) & & & \\
\hline & $\begin{array}{l}\text { 1. It takes a relatively long time and a considerable } \\
\text { cost }\end{array}$ & 0,1 & 3 & 0,3 \\
\hline & $\begin{array}{l}\text { 2. Sometimes the simulation is not always fully } \\
\text { able to create real-life situations. }\end{array}$ & 0,05 & 3 & 0,15 \\
\hline & $\begin{array}{l}\text { 3. The absence of real consequences for errors so } \\
\text { that participants are less performing and results } \\
\text { are not accurate }\end{array}$ & 0,05 & 2 & 0,1 \\
\hline & Amount & 1,00 & & 3,50 \\
\hline
\end{tabular}

Source: Result of Data, 2017

Based on the weighting results of internal factors of creative industry development through entrepreneurship training, it can be seen that the highest strength factor is developing individual skills so that participants can learn all aspects of their work, enabling trainees to perform high-risk activities in a safe environment dangerous implication, and can improve the skills of trainees and let learn from mistakes. The lowest factor is gaining experience on how to interact in the work environment and the absence of real consequences for errors so that the participants are not performing and the results are not 
accurate. This high-strength factor demonstrates that this aspect is a top priority to be maintained and enhanced over other aspects. As for the weakest aspect of the result is sometimes the simulation is not always fully able to create real-life situations into factors that need to get high priority while the factor lacks real consequences for errors so that the participants are not performing and the results are not accurate is the second priority.

\section{- External Factor Evaluation (EFE) Matrix}

External Analysis aims to identify opportunities and threats as well as to see the capability of entrepreneurship training conducted at UPTD BLK Kota Parepare in the face of changes in its external environment analyzed using EFE Matrix. The following table presents the results of the EFE Matrix processing.

Table 2.

Evaluation of External Factors of Creative Industry Development through Entrepreneurship Training

\begin{tabular}{llccc}
\hline No. & External Factors & $\begin{array}{c}\text { Weight } \\
\text { (a) }\end{array}$ & $\begin{array}{c}\text { Rating } \\
\text { (b) }\end{array}$ & $\begin{array}{c}\text { Value } \\
(\mathrm{a}) \times(\mathrm{b})\end{array}$ \\
\hline 1. & $\begin{array}{l}\text { Opportunities (+) } \\
\text { a. The existence of government policy in } \\
\text { developing entrepreneurship }\end{array}$ & 0,15 & 4 & 0,6 \\
b. Labour requirements & 0,2 & 4 & 0,8
\end{tabular}

2. Threat (-)

\begin{tabular}{|c|c|c|c|c|}
\hline & $\begin{array}{l}\text { Development participants have unequal } \\
\text { or heterogeneous backarounds }\end{array}$ & 0,15 & 4 & 0,6 \\
\hline b. & Trainers or instructors who are skilled and & 0,1 & 3 & 0,3 \\
\hline c. & $\begin{array}{l}\text { trainıng and education participants are } \\
\text { hard to come by. }\end{array}$ & 0,1 & 3 & 0,3 \\
\hline & $\begin{array}{l}\text { infrastructure needed for training and } \\
\text { education are very less or not good. }\end{array}$ & 0,1 & 2 & 0,2 \\
\hline d. & $\begin{array}{l}\text { The curriculum is defined and taught to } \\
\text { be less harmonious or distorted and not } \\
\text { systematic to support the target desired }\end{array}$ & & & \\
\hline & by the participant's effort. & 0,2 & 4 & 0,8 \\
\hline e. & $\begin{array}{l}\text { Funds available to developers are very } \\
\text { limited. }\end{array}$ & & & \\
\hline & Amount & 1,00 & & 3,6 \\
\hline
\end{tabular}

Source: Result of Data, 2017

Based on Table 2 above, it is known that the highest value for the aspect of the opportunity is the existence of government policy in developing entrepreneurship and manpower needs. This means the need factor of labour can be the main opportunity in developing creative industry through entrepreneurship training. Meanwhile, for the factors that become the highest-rated threat of funds available to developers is very limited. This gives an indication that the factor is a serious threat to the sustainability of creative industry development through entrepreneurship training going forward.

\section{Analysis of Internal and External matrix (I-E) and SWOT Matrix}

- Internal and External Matrices (I-E)

The I-E (Internal-External) matrix is generated through the incorporation of information obtained from the EFE and IFE matrices to gain information on the firm's position to facilitate the delivery of alternative strategies. The EFE matrix value of 3.6 indicates the 
development of creative industries through entrepreneurship training has a high ability in exploiting opportunities and avoiding existing threats. While the IFE matrix value of 3.5 indicates the development of the creative industry through entrepreneurship training has internal factors that are high in utilizing the strengths to overcome the existing internal weaknesses.

Based on the value of EFE and IFE matrix, the competitive position of creative industry development through entrepreneurship training in quadrant I. In that position, the best strategy is the strategy of developing creative industry through entrepreneurship training that is the fulfilment of labour requirement by increasing development fund or entrepreneurship training.

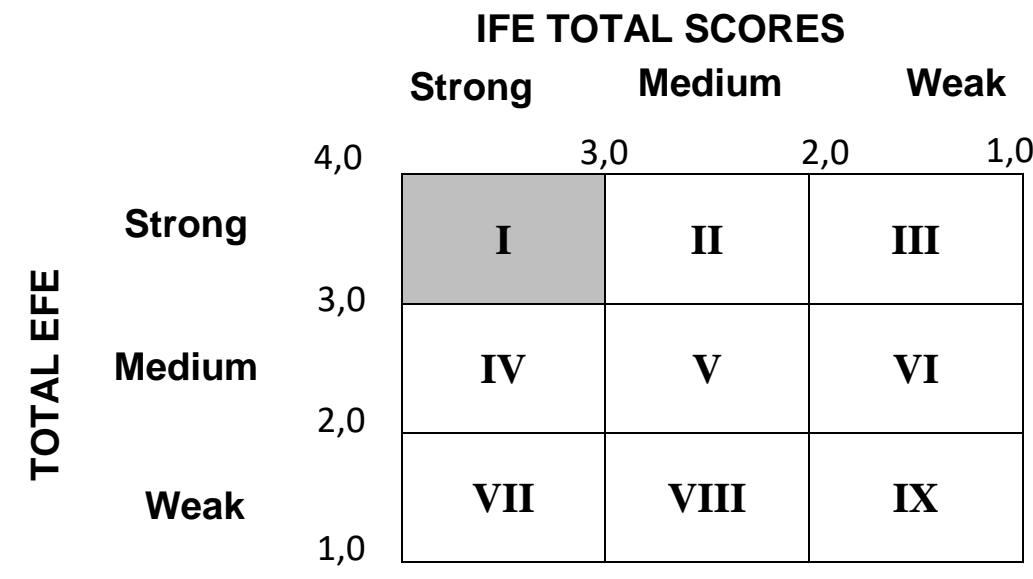

Figure 3. I-E Matrix of Small Industry Development through

Entrepreneurship Training

\section{SWOT Matrix}

Based on the assessment of internal factors and external factors above, formulated an alternative strategy of developing creative industry through entrepreneurship training in Parepare city using SWOT analysis in matrix form as in the following table.

Table 3.

SWOT Matrix of Creative Industry Development Strategy through Entrepreneurship Training in Kota Parepare

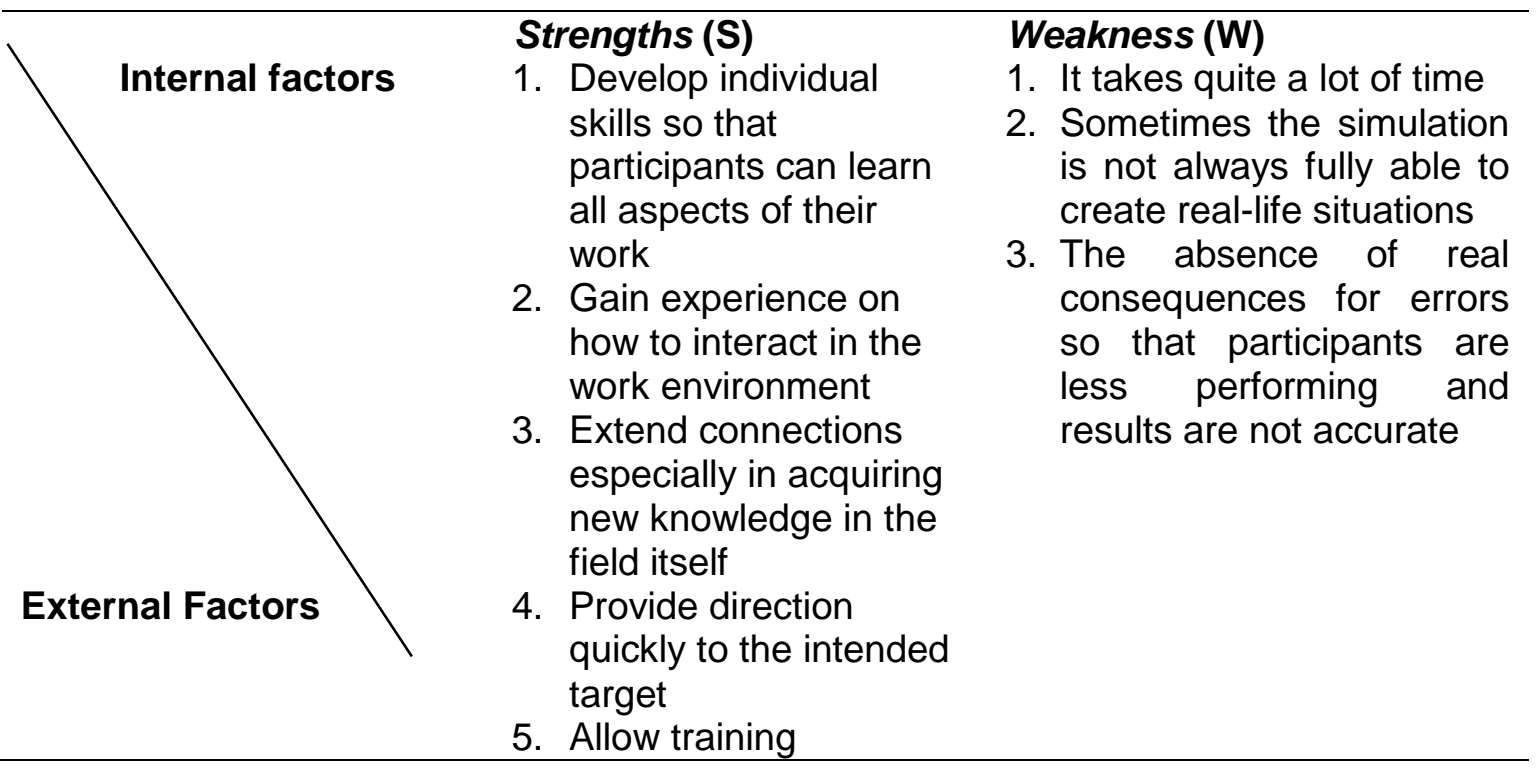




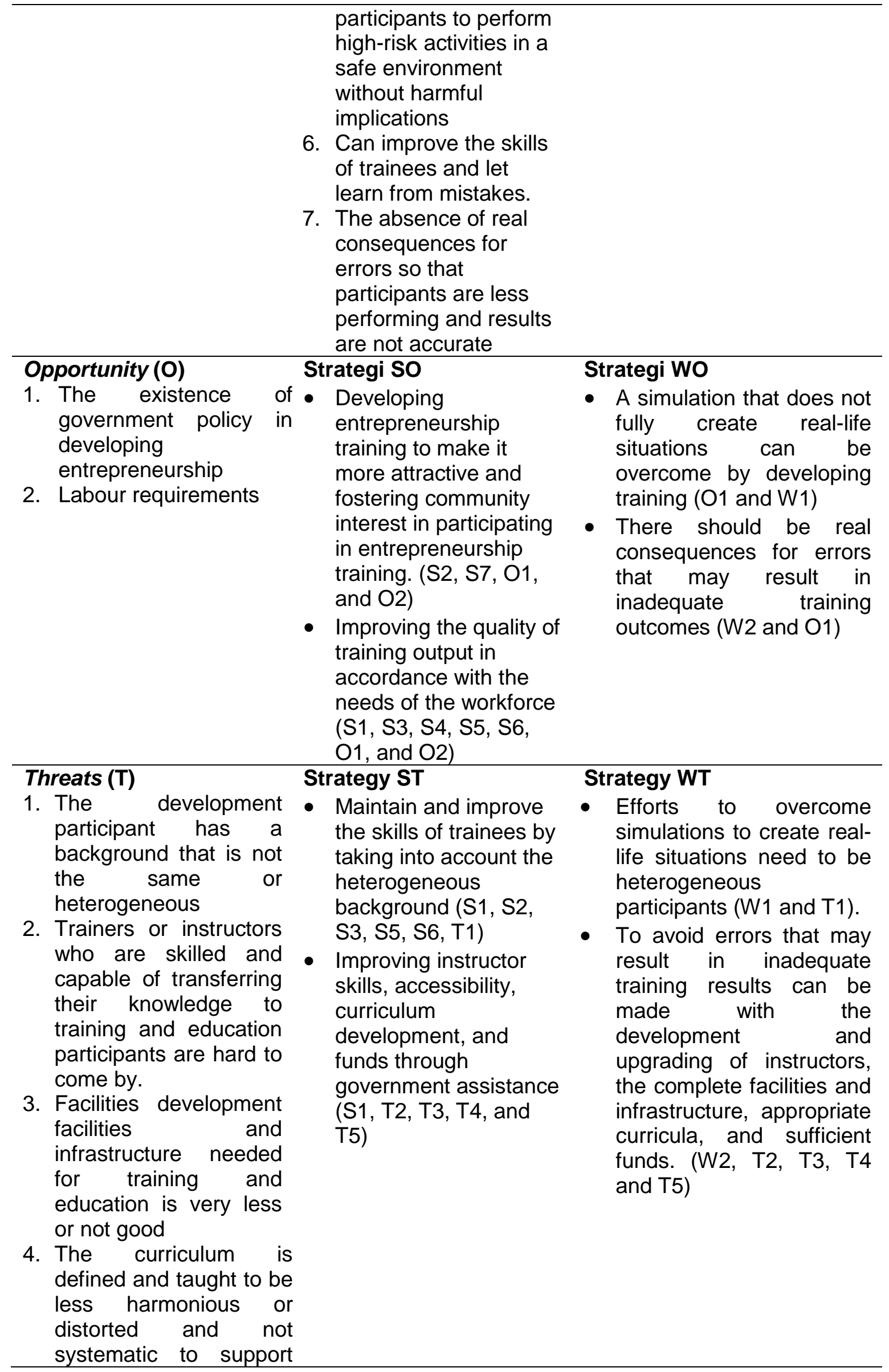


the target desired by the

business participants

concerned.

5. Funds available to

developers are very

limited.

Source: Result of Data, 2017

\section{The strategy of Developing Creative Industry Based on Entrepreneurship Training in Effort to Develop Local Economy}

Based on the results of research that has been done, can be identified several factors into the strengths, weaknesses, opportunities and threats faced by managers of entrepreneurship training, especially UPTD BLK Kota Parepare. Based on the results of EFE (External Factor Evaluation) and IFE (Internal Factor Evaluation) matrix analysis, it can be seen that creative industry development position through entrepreneurship training in Parepare City in Quadrant I. In that position, the best strategy is the strategy of graduate quality improvement through training development entrepreneurship. Overall from the analysis of these factors, can be formulated some business development strategies such as the following.

\section{1) Recruitment and Selection of Entrepreneurship Training Participants}

In conducting proper targeted training, it is necessary to design a training program as a guideline for training in UPTD BLK Kota Parepare. The training objectives are tailored to the level of industry/job market needs derived from the identification of training needs that exist in the local industry/ labour market. Under these conditions for the scope of Parepare City, the training needs identification activities should refer to the labour market climate conditions that show an increase in demand especially in the sector of creative industries based on local potential.

Each job training program is based on training needs data with reference to the Working Competency Standards established by the Minister of Manpower and Transmigration Decree with the pattern of Competency Based Training Standards. Thus, prospective entrepreneurship trainees should be recruited and selected in accordance with the training needs to be implemented. The application of the type and the test material in the selection process depends on the training program to be followed. Overall, the recruitment and selection process can be described as follows: (1) Disseminating information about the training program to be implemented as well as the requirements, (2) Registering prospective participants, (3) Preparing the list of candidate recapitulation, (4) Establishing a selection method (5) Selection of selection results, (7) Announcing the results of selection, (8) Preparing the list of participants who have been declared accepted, and (9) Creating the complete data trainees.

\section{2) Selection of Instructor of Entrepreneurship Training}

In essence, instructors are trainers who perform training. His role and task demanded success in training. Therefore, to succeed the training requires skilled instructors, able to play a role as a teacher, mentor, and motivator. Instructors are expected to increase their knowledge and improve the skills of trainees.

The task of the instructor in the implementation of entrepreneurship training is; (a) Helping the trainees in planning the training process, (b) Guiding the participants through the training tasks described in the training, (c) Helping to understand the concept and answering the questions of the trainees, (d) Helping to find additional sources of information required by the participants training, (e) Organizing group learning activities where appropriate, (f) Bringing in an expert from the workplace where necessary, (g) Testing / collecting evidence and making training progress notes for each trainee, and ) Evaluate the achievement of individual competencies. 


\section{3) Provision of Training Facility and Infrastructure}

Training facilities and infrastructure are the parts that have a very important role in the success and smoothness of a training process. Training facilities and infrastructure are facilities that are absolutely fulfilled to provide ease in organizing a training event, although not yet able to meet the facilities and infrastructure properly. UPTD BLK Kota Parepare as the party most responsible for the management of all activities held. In addition to providing, BLK is also obliged to maintain and maintain the infrastructure that has been owned.

\section{4) Curriculum Development}

The curriculum represents a number of training subjects and activities and everything that influences the personal formation of trainees according to the training objectives set by the government. The curriculum in a training system is a tool (instrumental input) that is very helpful in planning, implementing and evaluating a training program.

The curriculum becomes a tool or effort in achieving certain training/competency training objectives are considered quite precise and crucial to achieving. So one step that needs to be done is to review the goals that have been used by the relevant training institutions (Soetopo and Sumarno, 1993: 17). The point is that if the desired objectives have not been reached then it is necessary to review the tools used to achieve these objectives, for example by reviewing the curriculum.

Curriculum development should meet principles consisting of principles of relevance, efficiency, effectiveness, and flexibility. Attempts to achieve these goals depend on how the program is planned. For each planner or training designer, the main and final objective of a training is the change in the attitude of the participants in the form of behavioural changes (psychomotor).

\section{5) Provision of Training Fund/budget}

The effort to improve the quality of the training should be through improving the training process, and the training process will be of high quality if there is organized high financing. The calculation of the allocation of training costs should be done as accurately as possible in accordance with the components of training activities and unit costs if done then analyze all the use of training costs into steps that cannot be abandoned.

Training budgets are prepared on the basis of training needs that have been compiled in training programs that are usually compiled during the annual budgeting period of the government or training institution. Preparation of the budget can be done by referring to the proposed training from various units (departments) and programs that have been prepared by the training section. The objectives of the preparation of the training budget are: (1) Provide restrictions on the amount of funds used, (2) detail the types of fund sources so as to facilitate supervision, (3) rationalize the source of funds and investment funds in order to achieve maximum results, (4) which have been prepared because of the budget, more clearly and visibly visible, and (5) Accommodate and analyze and decide on any proposals related to cost.

Meanwhile, the benefits of training budget are: (1) All activities can be directed towards the achievement of common goals, (2) Can motivate the training manager because there are goals/targets to be achieved, (3) Raise the sense of responsibility of training manager, (4) Avoid waste and unnecessary payments, and (5) Resources that can be utilized as efficiently as possible.

\section{Conclusion}

1. The development of creative industries through entrepreneurship training in developing the local economy includes Information and Communication Technology, Garment Apparel, Beauty, Building, Electrical Engineering, Electronic Engineering, Refrigeration, Manufacturing Engineering, and Las Engineering.

2. The usefulness of implementing entrepreneurship training on creative industry development in developing local economy that can shorten the learning period to meet 
the specified performance standard, improve job performance, attitude formation, help solve daily company operational problems, prepare entrepreneurs to acquire expertise in certain fields that the company needs, and produce outcomes that have the ability and knowledge that qualified so that entrepreneurs gain a sense of security and value, and cause satisfaction in him.

3. Factors that support and hinder the development of creative industries through entrepreneurship training in developing the creative industries, namely (a) internal factors include strengths consisting of: Developing individual expertise, gaining experience of interacting in the work environment, expanding connections, providing direction quickly the intended target enables trainees to engage in high-risk activities in a safe environment without harmful implications, can improve skills by learning from mistakes, and participants are taught to think in action, to make effective decisions and communication, while their weakness consists of requiring time relatively long time and considerable cost, sometimes simulations are in harmony with real life, and there is no real consequence for errors so that participants are underperforming and results are inaccurate and (b) External factors include opportunities consisting on the existence of government policies in developing entrepreneurship and labor needs, while threats consist of backgrounds of heterogeneous participants, the difficulty of finding qualified and competent trainers or instructors, inadequate facilities and infrastructure, less harmonized or systematic curriculum with training objectives, and very limited funds.

4. Creative industry development strategy based on entrepreneurship training in the effort to develop a local economy that is recruitment and selection of trainees, selection of training instructors, provision of facilities and infrastructure, curriculum development, and provision of funds or training budget.

\section{SUGGESTION}

1. Training managers should develop other areas of entrepreneurship training in accordance with needs such as agricultural and plantation processing, printing, and so on.

2. Considering the usefulness of implementing entrepreneurship training on the development of creative industry in developing the local economy is very clear, the training managers should conduct entrepreneurship training routinely and continuously by taking into account local potentials.

3. Training managers should take advantage of factors supporting the development of creative industries through entrepreneurship training in overcoming inhibiting factors.

4. Training managers should conduct recruitment and selection of trainees and the selection of training instructors by taking into account the needs, and preparing adequate facilities and infrastructure, revising the curriculum according to field demands, and providing adequate funding or training budget.

\section{References}

Davis, G. B, .(1998). Kerangka Dasar Sistem Informasi Manajemen. Jakarta: PT. Gramedia. Departemen Perdagangan Republik Indonesia, 2007. Indonesia Creative Industry Study 2007. Jakarta: Departemen Perdagangan RI.

Dumairy. (1997). Perekonomian Indonesia. Jakarta. Erlangga.

Flippo, F. B., .(2002). Personel Management (Manajemen Personalia, Edisi. VII Jilid II, Terjemahan Alponso S, Jakarta: Erlangga.

Jerusalem, M. A. .(2012). Merintis dan Mengelola Bisnis Butik. Yogyakarta: Universitas Negeri Yogyakarta.

Kamil, Mustofa. (2010). Model Pendidikan Dan Pelatihan (Konsep dan Aplikasi). Bandung: Penerbit Alfabeta.

Moekijat. .(1991). Latihan dan Pengembangan Layanan Pegawai. Bandung. Mandar Maju. Simamora, H. .(1995). Manajemen Sumber Daya Manusia. Yogyakarta: STIE YPKN. 
Oikos: Jurnal Kajian Pendidikan Ekonomi dan IImu Ekonomi, ISSN Online : 2549-2284 Volume II Nomor 1, Mei 2018

Simatupang, M.T. (2008). Industri Kreatif untuk Kesejahteraan Bangsa. ITB Bandung: Inkubator Industri dan Bisnis.

Sudjana. (2007). Sistem dan Manajemen Pelatihan (Teori dan Aplikasi). Bandung: Falah Production.

Sukirno, S. (2002). Teori Mikro Ekonomi. Cetakan Keempat Belas. Rajawali. Press. 